\title{
Modified Methylene Blue Screening Method for Significant Bacteriuria
}

\section{Alo Moses Nnaemeka ${ }^{1}$ and Ugah Uchenna lyioku ${ }^{2 *}$}

${ }^{1}$ Department of Biological Sciences, Faculty of Science and Technology, Federal University, Ndufu - Alike Ikwo, Nigeria

${ }^{2}$ Department of Medical Biochemistry, Faculty of Basic Medical Sciences, Federal University, Ndufu - Alike, Ikwo, Nigeria

\begin{abstract}
Urinary tract infection is common in the tropics especially in third world countries. In most regional laboratories the volume of urine specimens requested for culture and sensitivity are so overwhelming that it poses a great pressure on the laboratory staff and also consumes a lot of reagent. Evidence abound to support the fact that less than $50 \%$ of all such specimen are positive hence the need for a screening method that will reduce the large quantity of urine specimen that will undergo culture. The screening for significant bacteriuria will therefore obviate the wastage of materials, reagent, hospital manpower and time. The modified methylene blue screening technique was performed by adding $20 \mu \mathrm{l}$ of methylene blue stain to $10 \mathrm{ml}$ of well mixed urine sample and allowed to stand at room temperature for 5 minutes before reading the absorbance at $540 \mathrm{~nm}$ wavelength against water blank. The absorbance of the sample is compared with that of the cut-off value and those that exceed this value are recorded as being positive for significant bacteriuria while those with absorbance below the cut-off value are recorded as being negative and should not be cultured. The results obtained from the screening technique were compared with semiquantitative urine culture results. A total of 2683 samples were assayed, among this $984(36.68 \%)$ had absorbance above the cut-off value and so were recorded as being positive for significant bacteriuria whereas 1699 $(63.32 \%)$ had absorbance below the cut-off value and were recorded as being negative for significant bacteriuria. When compared with the semiquantitative culture, a total of $933(34.85 \%)$ had isolates with significant bacterial growth of $\geq 10^{5} \mathrm{CFU} / \mathrm{ml}$ while $1748(65.15 \%)$ had either no bacterial growth or non-significant bacterial isolates. The technique showed a sensitivity of $94.82 \%$ and a specificity of $97.17 \%$. The difference in significant bacteriuria between the urinary screening technique and culture isolate was statistically significant $(p<0.05)$. We present our technique for further study while we advocate their adoption in clinical laboratories especially in poor resource setting in developing countries.
\end{abstract}

Keywords: Significant bacteriuria; Methylene Blue; Urinary screening; Sensitivity; Specificity

\section{Introduction}

Urinary tract infection is common in the tropics especially in third world countries. Most of the patients are treated as out-patients and the indiscriminate use of antibiotics without susceptibility testing has added a new dimension to the need for quantitative urine culture for the level of insignificant bacteriuria. In most regional laboratories the volume of urine specimens requested for culture and sensitivity are so overwhelming that it poses a great pressure on the laboratory staff and also consumes a lot of reagent resulting in wastage against the background of poor resources that is prevalent in most tropical laboratories. Evidence abound to support the fact that less than $50 \%$ of all such specimen are positive hence the need for a screening method that will reduce the large quantity of urine specimen that will undergo culture. The screening for significant bacteriuria will therefore obviate the wastage of materials, reagent and hospital manpower time.

Among the numerous urine samples that are investigated by hospital laboratories daily, only a small portion of about $25-30 \%$ are actually infected and require culture $[1,2]$. However, a reasonable amount of hospital resources, laboratory staff time and efforts are expended on the conventional method of diagnosing urinary tract infection which involves the quantitative or semi-quantitative culture of urine specimens on appropriate solid medium and reading the culture results after overnight incubation.

It is necessary that a screening method is introduced which will distinguish urine samples which do not have significant bacteriuria and so should not pass for urine culture from those that have significant bacteriuria and require to be processed further for culture.
Different screening methods which have been used to screen for significant bacteriuria include; automated photometric systems [3], measurement of bacterial adenosine triphosphate by luciferase [4], measurement of heat generated by metabolizing organisms [5], changes in electrical impedance [6], particle counting [7], chemical analysis [8], fluorescence staining using acridine orange [9], and filter staining techniques [10].

These methods have their various advantages; however, their cost make it virtually unaffordable in hospitals in poor resource settings of the tropics and other developing countries where there is harsh economic conditions and the absence of political will to revitalize the health sector. The purpose of this study was to evaluate alternative methods for screening of significant bacteriuria in hospital laboratories with resources that are easily affordable and commercially available.

\section{Materials and Methods}

\section{Ethical consideration}

Ethical clearance was sought for and obtained from the ethical

*Corresponding author: Uchenna lyiokuUgah, Federal University NdufuAlike Ikwo, Abakaliki, Ebonyi State, Nigeria, Tel: 234 7062154353; E-mail: ugahuchennaiyioku@gmail.com

Received January 09, 2014; Accepted February 05, 2014; Published February 09, 2014

Citation: Nnaemeka AM, lyioku UU (2014) Modified Methylene Blue Screening Method for Significant Bacteriuria. Clin Microbial 3: 139. doi:10.4172/23275073.1000139

Copyright: @ 2014 Nnaemeka AM, et al. This is an open-access article distributed under the terms of the Creative Commons Attribution License, which permits unrestricted use, distribution, and reproduction in any medium, provided the original author and source are credited. 
Citation: Nnaemeka AM, Iyioku UU (2014) Modified Methylene Blue Screening Method for Significant Bacteriuria. Clin Microbial 3: 139. doi:10.4172/2327-5073.1000139

Page 2 of 2

committee of Federal Teaching Hospital Abakaliki. Informed consent was also obtained from the subjects.

\section{Study population}

The study was conducted among patients attending Federal Teaching Hospital, Abakaliki for which urinary tract infection was suspected and urine culture had been requested by the clinicians.

\section{Specimen collection}

Urine samples were collected into sterile screw capped universal containers. The patients were given written and oral instruction on aseptic methods of collecting midstream urine. The instruction emphasized among other things that the patients wash their hands and genitals with soap and water before sample collection. At least $15 \mathrm{mls}$ of the samples were collected. A total of two thousand six hundred and eighty three consecutive urine samples were collected by confidence sampling and analyzed.

\section{Sample Analysis}

\section{Semiquantitative urine culture}

All the samples were cultured on 5\% blood agar (Oxoid Limited, Wade road, Basingstoke, Hampshire, UK), MacConkey agar and Cysteine Lactose Electrolyte Deficient agar (Lab M Limited, Topley house, 52 Welsh lane, Lancashire, UK) using a standard $0.01 \mu \mathrm{l}$ platinum wire loop. After overnight incubation at $37^{\circ} \mathrm{C}$, the plates were examined for significant bacterial growth $\left(\geq 10^{5} \mathrm{CFU} / \mathrm{ml}\right)$. All the media were prepared following strict adherence to the manufacturer's instructions.

\section{Modified Methylene Blue screening method}

The standard was prepared by adding $20 \mu \mathrm{l}$ of methylene blue to $10 \mathrm{ml}$ of normal saline. For each sample, $20 \mu \mathrm{l}$ of methylene blue was added to $10 \mathrm{ml}$ of well mixed urine samples and allowed to stand at room temperature for five minutes. The absorbance of the samples and standard were read at $540 \mathrm{~nm}$ wavelength against water blank. The absorbance of the standard was read first and the value obtained was taken as the cut-off value. Samples with absorbance less than or equal to the cut-off value were labeled negative (not having significant bacteriuria) while samples with absorbance greater than the cut-off value were labeled positive (having significant bacteriuria). The results obtained from the screening were compared with the results obtained from the semiquantitative urine culture and analyzed for significant bacteriuria.

\section{Specificity and Sensitivity}

The specificity and sensitivity of the screening technique was calculated, specificity was calculated as [(true negative result/true negative result+false positive result) $] \times 100$ while the sensitivity was calculated as [(true positive result)/(true positive results+false negative results) $] \times 100$.

\section{Data analysis}

The data obtained was analyzed using simple descriptive statistics and Chitest, $\mathrm{P}$ value was considered significant at $95 \%$ confidence interval. Data analysis was done with the aid of Statistical programme for social sciences (SPSS) version 18.0.

\section{Result}

A total of two thousand six hundred and eighty three (2683) urine samples were screened for significant bacteriuria using modified

\begin{tabular}{|l|c|c|}
\hline \multirow{2}{*}{ Bacteria isolate } & \multicolumn{2}{|c|}{ Colony Count } \\
\cline { 2 - 3 } & $10^{4}-10^{5}$ & $\geq 10^{5}$ \\
\hline Escherichia coli & 61 & 195 \\
\hline Pseudomonas aeruginosa & 28 & 126 \\
\hline Klebsiellaspp & 34 & 73 \\
\hline Staphylococcus aureus & 56 & 72 \\
\hline Proteus mirabilis & 27 & 79 \\
\hline Proteus vulgaris & 23 & 39 \\
\hline Enterobacterfeacalis & 11 & 43 \\
\hline GroupB Streptococci & 09 & 04 \\
\hline GroupD Streptococci & 02 & 06 \\
\hline Coagulasenegative Staphylococci & 05 & 17 \\
\hline Staphylococcus saprophyticus & 02 & 05 \\
\hline Enterococcus spp & 05 & 03 \\
\hline Serratiamarcescens & 02 & 01 \\
\hline
\end{tabular}

Table 1: Significant bacteria isolates from the samples analyzed and their colony counts (CFU/MI).

methylene blue screening method. The samples were subsequently cultured on different media. The culture plates were read after overnight incubation and the isolated colonies were counted and characterized. The bacteria isolated from the samples and their colony counts are presented in Table 1 . The results obtained from urine culture were compared with that obtained from urine screening technique for significant bacteriuria for each sample using the criterion of $\geq 10^{4} \mathrm{CFU} /$ $\mathrm{ml}$ for significant bacteriuria [11].

Among the overall samples, a total of 933 (34.85\%) had isolates with significant bacterial growth of $\geq 10^{5} \mathrm{CFU} / \mathrm{ml}$ while 1748 (65.15\%) had either no bacterial growth or non-significant bacterial isolates. Among this number, $35.81 \%$ (626 of 1748) had non-significant bacterial isolates while $64.19 \%$ (1122 of 1748) had no bacterial growth.

Among the samples screened, a total of 984 (36.68\%) had absorbance above the cut-off value and so were recorded as being positive for significant bacteriuria whereas 1699 (63.32\%) had absorbance below the cut-off value and were recorded as being negative for significant bacteriuria.

The sensitivity and specificity of the modified urinary screening method was compared, using semiquantitative urine culture as the standard to determine the values with true positive results for those with significant bacteriuria and true negative results for samples with non-significant bacteriuria. The technique showed a sensitivity of $94.82 \%$ and a specificity of $97.17 \%$. The difference in significant bacteriuria between the urinary screening technique and culture isolate was statistically significant $(\mathrm{p}<0.05)$.

\section{Discussion}

Ideally, a screening test for bacteriuria should provide rapid useful information and eliminate the need for unwarranted urine culture [12]. This is important because laboratory demand reveals an increasing workload on the urine specimens that require culture. Therefore, there is a need to screen out the samples that are potentially negative for bacteriuria [13].

Developing countries are marred by indiscriminate abuse of antimicrobial agents with impunity; virtually all of these drugs are available to the public and can be bought and consumed without prescription. To add to this, there is increased practice of empirical prescription by clinicians in which antimicrobials are prescribed without antibiotic susceptibility results from the hospital laboratories. 
Citation: Nnaemeka AM, Iyioku UU (2014) Modified Methylene Blue Screening Method for Significant Bacteriuria. Clin Microbial 3: 139. doi:10.4172/2327-5073.1000139

Page 3 of 2

Besides the increase in resistant strains of different microorganisms, the laboratories are faced with isolation of non-significant bacteriuria even in the presence of numerous signs and symptoms of urinary tract infection.

On daily basis, the hospital laboratory staff is confronted with extremely large amount of urine samples accompanied by request forms for urine culture. However, after processing and incubation, more than $60 \%$ of the samples do not yield significant bacterial growth. Numerous techniques that are already available for screening of urine samples for significant bacteriuria cannot adequately be used in tropical and district hospital laboratories because of economic cost, frequent breakdown of the equipments, lack of preventive maintenance among others.

Different studies have been conducted among other bacteriuria screening methods in clinical laboratories. One of such was conducted among Chemstrip LN, Bac-T- screen and ATP assay, and concluded that none of the three methods were sufficiently sensitive for use in hospital laboratories [14]. Another evaluated six screening methods including electrical impedance, automated acridine-orange staining, particle counting, bioluminescence, nitrite and leucocyte strip test and microscopy [15]. These methods were determined to have high sensitivities of $83-100 \%$ but low levels of specificities of $68-79 \%$ [15]. There has therefore been a yearning by district hospital laboratories for a screening method that can be used to screen urine samples for significant bacteriuria and as such conserve laboratory resources and manpower time.

Our modified screening method for significant bacteriuria can be easily performed by all laboratory staff using spectrophotometer which is available in every district laboratory. The method only uses methylene blue as the reagent, it yielded a sensitivity of $94.82 \%$ and a specificity of $97.17 \%$. Time of analysis is approximately 10 minutes which makes it time and cost effective

The mechanism for the staining capacity of methylene blue on the screening method is still being studied. However the increased concentration of bacteria can raise the intensity of the mixture and as such raise the absorbance of urine samples with significant bacteriuria over the absorbance of the standard. We present our technique for further study while we advocate their adoption in clinical laboratories especially in resource constrained settings in developing countries.

\section{References}

1. Alexander MK, Khan MS, Dow CS (1981) Rapid screening for bacteriuria using a particle counter, pulse-height analyser, and computer. J ClinPathol 34: 194198.

2. Curtis GD, Johnston HH, Hack AR (1987) Automated bacteriuria screening using the Berthold LB 950 luminescence analyser. Eur J ClinMicrobiol 6: 275280.

3. Pezzlo MT (1983) Automated methods for detection of bacteriuria. Am J Med 75: 71-78.

4. Mackett D, Kessock-Philip S, Bascomb S, Easmon CS (1982) Evaluation of the Lumac kit for the detection of bacteriuria by bioluminescence. J ClinPathol 35: 107-110.

5. Beezer AE, Bettelheim KA, Newell RD, Stevens J (1974) The diagnosis of bacteriuria by flow micro-calorimetry, a preliminary investigation. Science Tools 21: 13-15.

6. Baynes NC, Comrie J, Prain JH (1983) Detection of bacterial growth by the Malthus conductance meter. Med Lab Sci 40: 149-158.

7. Dow CS, France AD, Khan MS, Johnson T (1979) Particle size distribution analysis for the rapid detection of microbial infection of urine. J ClinPathol 32: 386-390.

8. JuchuaVS, and Nauschuetz WF (1984) Evaluation of a leucocyte esterase and nitrite strip test for detection of bacteriuria. Current Microbiology 11: 119-122.

9. Scholefield J, Manson R, Johnston RJ, Scott R (1985) The use of acridine orange staining and image analysis to detect bacteriuria. Urol Res 13: 141-142.

10. Pfaller MA, Baum CA, Niles AC, Murray PR (1983) Clinical laboratory evaluation of a urine screening device. J ClinMicrobiol 18: 674-679.

11. KASS EH (1956) Asymptomatic infections of the urinary tract. Trans Assoc Am Physicians 69: 56-64.

12. Schifman RB, Wieden M, Brooker J, Chery M, Delduca M, et al. (1984) Bacteriuria screening by direct bioluminescence assay of ATP. J ClinMicrobiol 20: 644-648.

13. Johnstone HH, Mitchell CJ, Curtis GDW (1976) Automation in clinical microbiology: a system for urine specimens. In: Johnstone $\mathrm{HH}$, Newson SWB (eds.) Rapid Methods and automation in microbiology, 2nd international symposium. Oxford: (Europe), Learned Information 210-213.

14. Wu TC, Williams EC, Koo SY, MacLowry JD (1985) Evaluation of three bacteriuria screening methods in a clinical research hospital. $J$ ClinMicrobiol 21: 796-799.

15. Smith TK, Hudson AJ, Spencer RC (1988) Evaluation of six screening methods for detecting significant bacteriuria. J ClinPathol 41: 904-909. 